\title{
Mutations in Burnt-Clay Brick Properties attributable to Waste Glass
}

\author{
Ahsan Ali ${ }^{1}$, Fatima Hanif ${ }^{2}$, Nazam Ali ${ }^{3 a}$, Muhammad Nadeem ${ }^{3 b}$, \\ Muhammad Usman Rashid ${ }^{3 \mathrm{c}}$
}

RECEIVED ON 11.04.2020, ACCEPTED ON 20.12.2020

\begin{abstract}
Recently, the need of high living standards and developments in modern technology have significantly increased the usage of throwaway glass products. The use of these waste glass products in the production of construction materials (especially bricks) is ultimately very wholesome approach towards sustainable development. In this study, wasted glass up to $20 \%$ by weight was added to observe its impacts on bricks. The bricks containing powder glass were burnt along with ordinary bricks (with no powder glass) in same kiln and under same condition (type of fuel, temperature, duration $e t c$.). The results illustrated that the properties of bricks vividly improved such as areal density, water absorption and efflorescence. The $20 \%$ increase of waste glass in the brick samples resulted in $14 \%$ decrease in areal density. The addition of fine powder glass filled the pores and reduced porosity of bricks. The substantial reduction in water absorption of $26.14 \%$ were observed with $20 \%$ addition of waste glass content. Also efflorescence was less in specimens having less quantity of waste glass burnt at higher temperatures. The present study presented a comprehensive analysis of waste glass as a mixing component for producing light weight sustainable bricks with improved water absorption properties.
\end{abstract}

Keywords: Waste Glass Power, Burnt Clay Bricks, Ecological Construction Material

\section{INTRODUCTION}

I $n$ the recent decades, the need of the advanced living standards have imparted a significant pressure on the use of glass as a recycle material in different industries for sustainable point of view [1]. From economic feasibility point of view, the unprecedented increase of waste glass specifically from the beverages sector, requires technical solutions for recycling [2]. The use of the waste glass for manufacturing of building materials (i.e., building blocks, bricks) have enabled the reduction of the consumption of the natural resources as well as the cost of the waste disposal by protecting the environment from harmful effects of waste materials
$[3,16]$.

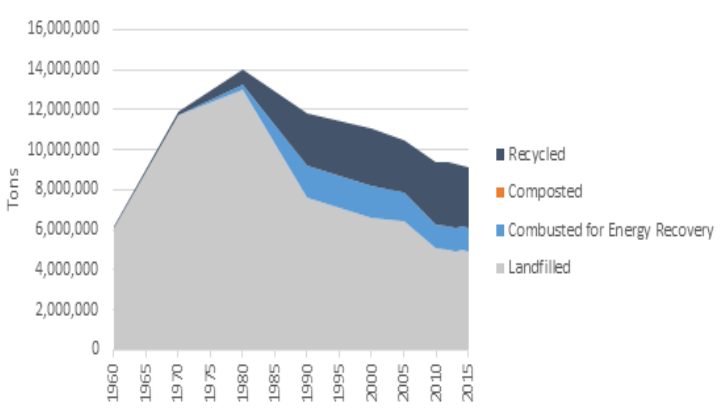

Fig. 1: Glass waste management: $1960-2015$

Glass, due to its properties (i.e., taking any shape, brighter surface, resistance against abrasion) has

${ }^{1}$ National Engineering Services of Pakistan (Pvt.) Ltd, Lahore, Pakistan. Email: malik.ahsan@ @ive.com

${ }^{2}$ Department of Civil Engineering, University of Engineering and Technology, Lahore, Pakistan.

Email: engr.fatimaramay@gmail.com (Corresponding author)

${ }^{3}$ Department of Civil Engineering, School of Engineering, University of Management and Technology, Lahore, Pakistan.Email: ${ }^{a}$ nazam.ali@umt.edu.pk, ${ }^{b}$ muhammad.nadeem@umt.edu.pk, ${ }^{c}$ civil.cod@umt.edu.pk

This is an open access article published by Mehran University of Engineering and Technology, Jamshoro under CC BY 4.0 International License. 
become necessary in life as a safe and sustainable reuse material [4].

With the increased usage of glass, the amount of waste glass disposal is also increased [5]. According to the United Nations study, an approximate amount of 200 million tons of solid waste is disposed of annually, amounting $7 \%$ of the glass waste [6]. Currently, glass has been used as an important material for the manufacturing and fabrication of tiles, insulation and reinforcement of fibers, foams glass, and different glass-ceramic compositions [1]. Because of an enormous amount of waste glass waste, as shown in Fig.1, it has been used as a recycled material produced from empty bottles of cold drinks, chemicals, and cosmetics etc., in the manufacturing of paving materials, lightweight concretes, block materials, and glass tiles [7-10]. The use of waste glass in the ceramic industry has been very useful and beneficial application of the glass produced from industrial and municipal activities. It is processed in a controlled environment including nucleation and crystallization [11]. The use of waste glass is especially beneficial in reducing the cost of natural resources consumption and protecting the environment from excessive disposal of glass waste [13]. Many of the researchers [2, 11-14] have suggested that glass from vitrified ceramic bodies is a very reliable and suitable source of glass recycling. So, it can be said very confidently that waste glass from ceramic industry have become a raw material for manufacturing of alternative sustainable material [2].

Based on the literature above, the use of the waste glass as a recycled material for the manufacturing of different construction materials is evident. In this research study, waste glass was used to produce bricks batches based on the conventional production lines.

\section{RESEARCH SCOPE OBJECTIVES}

AND

This study was intended to investigate the impacts of waste glass on the properties of fired-clay bricks. Powdered waste glass was added into brick clay at a ratio of $0 \%$ (control sample), 5\%, 10\%, 15\% and 20\% by weight of ordinary clay brick. Extrusion pressing mechanism was used to produce four different test samples based on the percent glass added. Samples were fired at kiln and in laboratory. Following points summarize the core objectives of this research study.

(i) The main objective of this study was to investigate the effect of waste glass addition on the properties of fired clay brick.

(ii) To utilize waste powder glass in burnt clay bricks and get the inference about the variation on properties of bricks like, areal density, water absorption, efflorescence etc.

(iii) To accommodate powder glass in brick industry and use it as raw material for production of brick units.

(iv) To craft an efficient method for reuse of waste glass with clay in bricks

(v) To make identification of powder glass as valuable product that could be used for production of brick units.

\section{METHODOLOGY}

\subsection{Preparation of Raw Materials}

For the bricks manufacturing process, a traditional method was carried out at Punjab Bricks. This kiln is a Bull Trench Type and located at Multan Road, Lahore, Pakistan (Fig. 2). In the present research study clay and waste glass powder were used as raw materials. Clay for bricks manufacturing process was taken from kiln's surrounding area on Multan road, 28 $\mathrm{km}$ away from Lahore, Pakistan. Impurities like plastic bags, organic waste, glass, gravels were removed from clay because their presence could create hindrance in later stages of mixing. Large lumps of clay were broken down to get homogenous particles (Fig. 3). The waste glass from local recycling supplier was further grinded to get the powder (Fig. 4). The

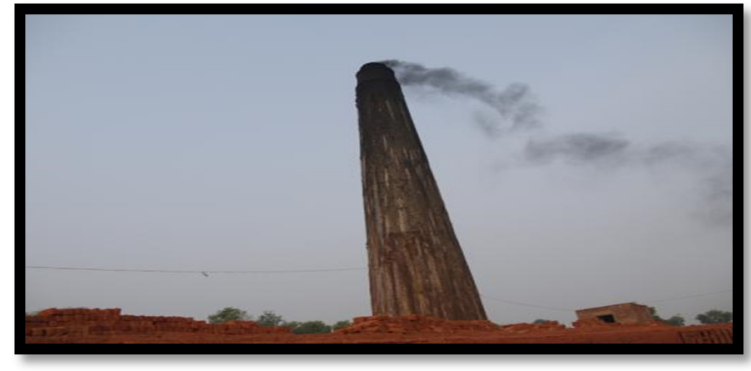

Fig. 2: Punjab Bricks (Bhatta on Multan Road)

Mehran University Research Journal of Engineering and Technology, Vol. 40, No. 4, October 2021 [p-ISSN: 0254-7821, e-ISSN: 2413-7219] 


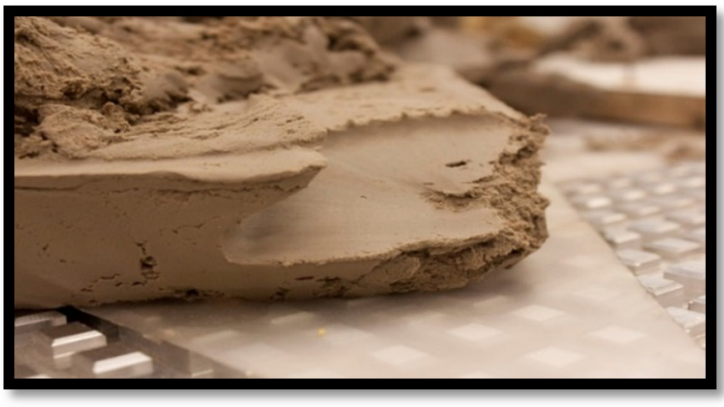

Fig. 3: Clay used for brick samples

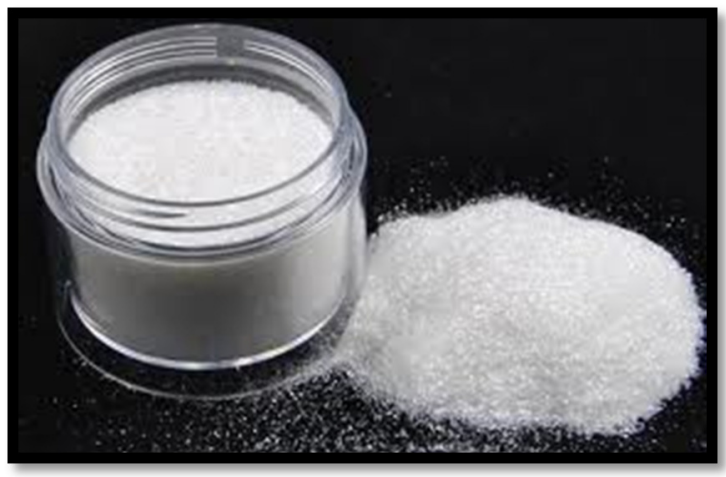

Fig. 4: Glass powder used in brick samples

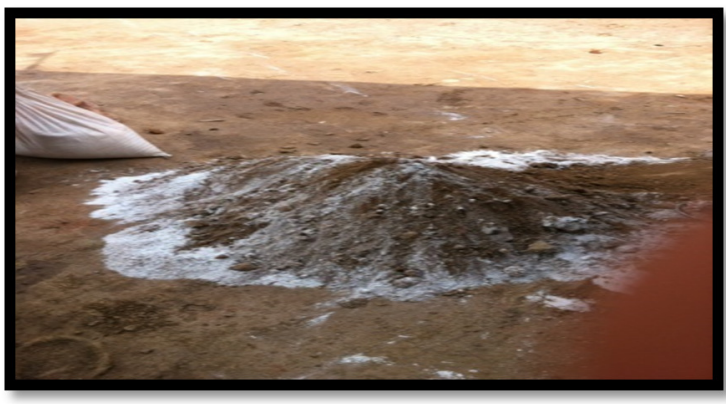

Fig. 5: Mixing mechanism of brick sample preparations

In the present research study, clay and powder glass in required amounts were mixed with controlled design proportions. According to the mix design, different percentages of waste glass powder ranging from $0 \%$ to $20 \%$ were mixed with clay in preparation of specimens[17].

\subsection{Mix Design}

We used in research the Clay material which has following chemicals properties Muscovite (52\%), Quartz-SiO 2 (32\%), Chlorite (10\%), Calcite-CaCO3 (5.5\%), Chlorides (0.7\%), Alkali- $\mathrm{Na}_{2} \mathrm{O}(0.15 \%), \mathrm{pH}-$ Value $(8.9 \%)$, and waste glass material has subsequent chemical properties Quartz-SiO $\mathrm{Si}_{2}$ (64\%), Lime-CaO (13.5\%), Chlorides (0.65\%), Alkali $\mathrm{Na}_{2} \mathrm{O}$ (14\%), pHValue $(9.8 \%)$.

\subsubsection{Specimens Preparation Process}

After completely mixing of the ingredients water was added in the mix. The resulting mixture of Clay (C) and Waste Glass (WG) is shown in Fig. 5.

Five types of mixes were made with clay and powder glass, in which powder glass content of $0 \%, 5 \%, 10 \%$, $15 \%, 20 \%$ by weight of ordinary clay brick was added.

In present research study, each mix was designed to make 30 samples of brick (150 in total) of each percentage of powder glass added. The design specification for one brick of each specimen are given in Table 1.

\begin{tabular}{|c|c|c|c|c|}
\hline \multicolumn{5}{|c|}{ Table 1: Mix Design for Specimen Preparation } \\
\hline Specimen & $\begin{array}{c}\mathrm{C}: \text { WG } \\
\left(\begin{array}{c}\% \\
\%\end{array}\right.\end{array}$ & $\begin{array}{c}\text { Clay } \\
\text { Kg }\end{array}$ & $\begin{array}{c}\text { WG } \\
\text { Kg }\end{array}$ & $\begin{array}{c}\text { Water } \\
(\mathrm{L})\end{array}$ \\
\hline $0 \% \mathrm{WG}$ & $100: 0$ & 3.50 & 0 & 3.5 \\
\hline $5 \% \mathrm{WG}$ & $95: 5$ & 3.325 & 0.175 & 3.325 \\
\hline $10 \% \mathrm{WG}$ & $90: 10$ & 3.15 & 0.315 & 3.15 \\
\hline $15 \% \mathrm{WG}$ & $85: 15$ & 2.975 & 0.446 & 2.975 \\
\hline $20 \% \mathrm{WG}$ & $80: 20$ & 2.8 & 0.56 & 2.8 \\
\hline \multicolumn{5}{|c}{ WG = Waste Glass, C = Clay } \\
\hline
\end{tabular}

The weight of clay brick which was used in calculations was $3.5 \mathrm{~kg}$. For molding process, conventional Hand molding method was used. For the purpose, the surface was prepared by leveling the ground and removing the waste material present on the ground surface. After molding process, the specimens were dried in sun for period of one week so that brick specimens should become hard enough to be carried and transported to kiln as shown in Fig. 6.

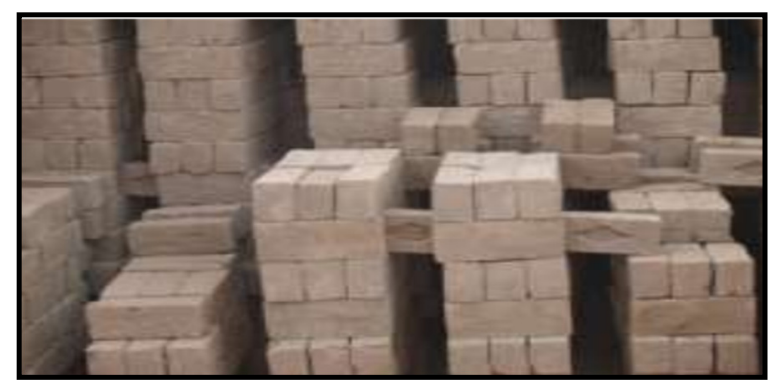

Fig. 6: Placement of bricks in kiln

Mehran University Research Journal of Engineering and Technology, Vol. 40, No. 4, October 2021 [p-ISSN: 0254-7821, e-ISSN: 2413-7219] 
After the drying process, the dried brick samples were placed and baked in Bull's Trench kiln with single chimney. The kiln was loaded with dried bricks in sections having six inches space for circulation of air current. To control the hot gases, the top surface of the brick section was covered with earth and ashes. Total 50 brick samples were placed in kiln for 45 days. These bricks were fired in the kiln for 36 hours. After 45 days, the burnt bricks were removed from the kiln.

In order to study the properties of prepared brick samples under controlled environmental conditions the remaining 100 bricks were used in laboratory analysis. The temperature ranges of 900,950 and $1000^{\circ} \mathrm{C}$ were used in laboratory oven for baking of sun dried bricks. The oven temperature was set to increase gradually to reach the desired baking temperature from 900 to $1000^{\circ} \mathrm{C}$. Fig. 7 illustrates the burnt brick simple after burning in laboratory oven. The detail of temperature increment scheme is given in Table 2.

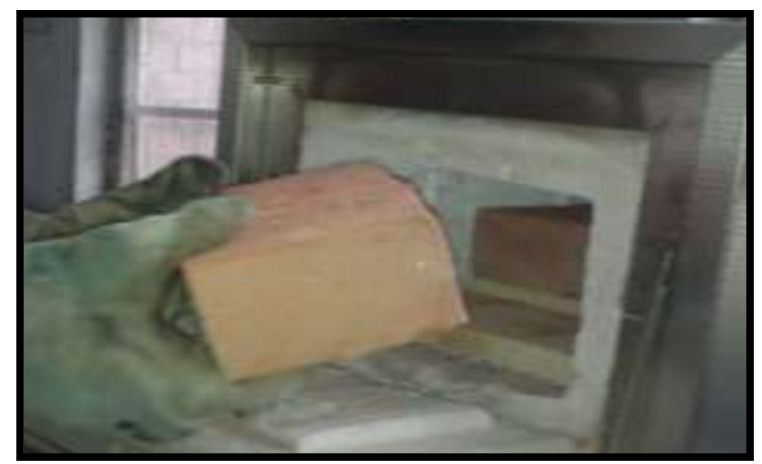

Fig. 7: Brick specimen after burning in electric oven

\begin{tabular}{|c|c|}
\hline \multicolumn{2}{|c|}{ Table 2: Gradual increase in burning temperature } \\
with time \\
\hline Timing (hrs.) & Desired Temperature $\left({ }^{\circ} \mathrm{C}\right)$ \\
\hline $0-1$ & 200 \\
\hline $1-2$ & 500 \\
\hline $2-36$ & 1000 \\
\hline
\end{tabular}

\subsection{Experimental Scheme}

An experimental methodology was applied on both kiln and oven burnt specimens. The experimental program was followed by ASTM C67-03a [15]. ASTM C67-03a [15] recommends that minimum 10 brick samples should be tested for each stack with 100000 numbers of bricks. In specimen testing, it was made ensured that the manufactured brick samples were free from dust or any other material that was not a part of mix design. The properties of the brick samples such as areal density, water absorption and efflorescence were determined.

\subsubsection{Areal Density}

The procedure given in ASTM C67-03a [15] was used to calculate areal density of brick. The necessary precautions were taken as mentioned in ASTM C6703a [15].

\subsubsection{Water Absorption}

The percentage amount of water absorption for a brick was found by performing an experiment given in ASTM C67-03a [15]. The quantity of water absorbed by bed face of block in one minute is called initial rate of absorption (IRA). In order to determine IRA value a test was performed according to ASTM C67-03a [15]. For a brick masonry, the capacity of water absorption of a brick unit and the water retaining ability of mortar for proper cement hydration decides the strength and quality of bond. The IRA value which is considered to be optimum is between 0.5 and 1.5 $\mathrm{Kg} / \mathrm{m}^{2} / \mathrm{min}$.

\subsubsection{Efflorescence}

The appearance of soluble salt on the surface of dry brick is called efflorescence. In order to find this property of brick ASTM C67-03a [15] test methods were used. Efflorescence is result of type of raw materials used to make bricks.

\section{RESULTS}

Based upon above-mentioned testing methodology, this research study gave following results.

\subsection{Areal Density}

To find out the areal density of the brick samples, the brick samples were oven dried at $110^{\circ} \mathrm{C}$ for the period of 24 hours and then cooled down at room temperature for about 5 hours. After cooling, brick samples were weighted by using electric weighing balance with least count of $0.01 \mathrm{~g}$. 
From the experimental analysis, it was seen that areal density of bricks samples decrease as percentage of waste glass increases. Same trend of areal density was observed for both kiln and oved dried brick samples (Fig. 8, (a, b)). Weight per unit area of ordinary clay brick was $133 \mathrm{~kg} / \mathrm{m}^{2}$ and brick specimen containing $20 \%$ waste glass burnt at $950^{\circ} \mathrm{C}$ has weight per unit area of $122 \mathrm{~kg} / \mathrm{m}^{2}$. This result illustrated that $14 \%$ decrease in areal density was calculated for the brick specimen having $20 \%$ waste glass content at temperature of $950^{\circ} \mathrm{C}$ as compared to brick specimen having ordinary clay. This can be concluded that the areal density of waste glass powder is comparatively lower than that of ordinary clay, which consequently decreases the weight of the burnt bricks. It is clear from the graph that burning temperature is inversely proportional to areal density of burnt brick specimen.

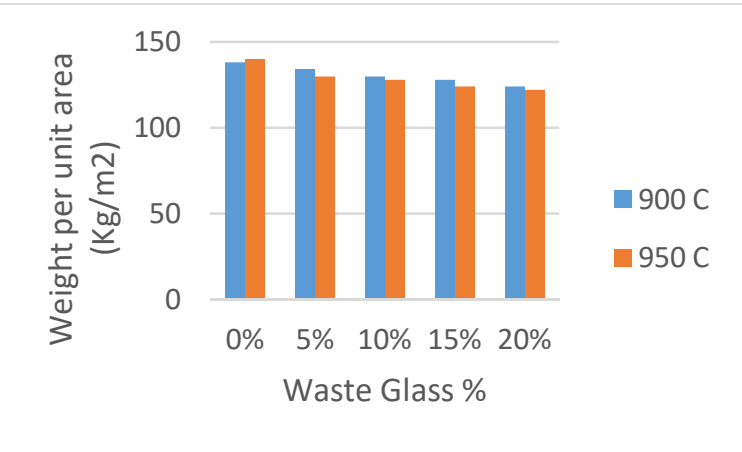

(a)

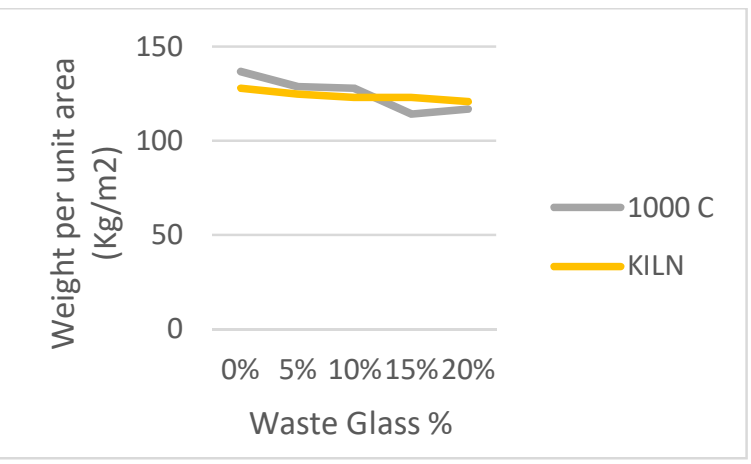

(b)

Fig. 8: Percent of waste glass added vs. weight per unit area at different temperatures

\subsection{Water Absorption}

According to the standard test procedure for water absorption of the bricks, the brick samples were submerged in water at room temperature for 24 hours
(Fig. 9). Afterwards, the brick specimens were cleaned with cloth. According to ASTM C67-03a [15] standards, water absorption can be calculated as

Water Absorption $=(\mathrm{Ws}-\mathrm{Wd} / \mathrm{Wd}) \times 100$

where $\mathrm{Wd}=$ Dry weight of brick specimen and $\mathrm{Ws}=$ Saturated of the bricks specimen

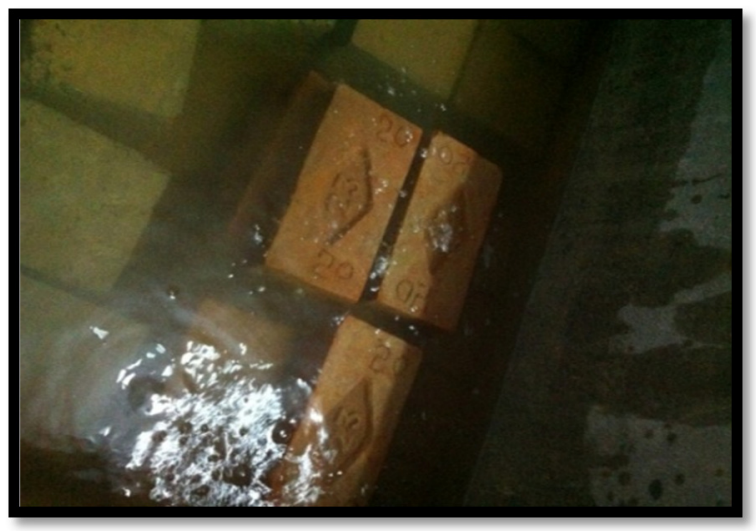

Fig. 9: Bricks submerged in water

Water absorption results for different waste glass percentage at different burning temperature in kiln and laboratory are shown in Fig. 10. Results illustrate that the water absorption capacity of brick samples decreased as the percentage of waste glass increases. The same trend of decrease in water absorption was observed in both kiln and laboratory oven dried specimen. This can be mainly due to zero water absorption ability of powder glass. Furthermore, it was also observed that water absorption capacity of the brick sample is inversely to burning temperature.

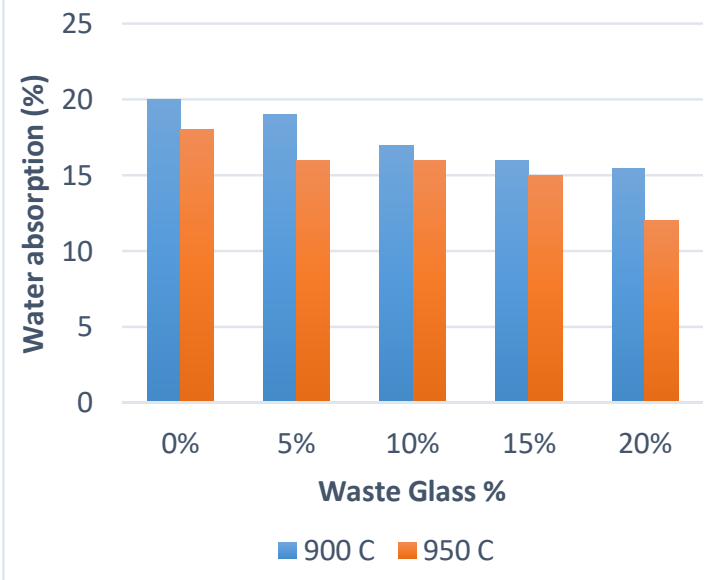

10 (a) 


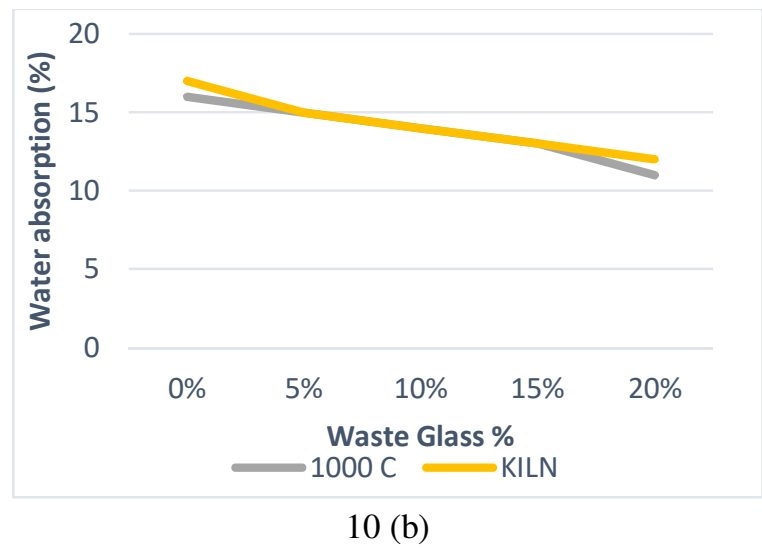

Fig. 10: Percent of waste glass added vs. water absorption at different temperatures

In order to find efflorescence a test was performed according to ASTM C67-03a [15] standards. Brick samples were placed in 1 inch deep water container for 7 days. After the testing period, the brick specimen were removed and visually examined for efflorescence. Consequently, no efflorescence was observed after 7 days (standard observation time according to ASTM C67-03a) [15]. However, the efflorescence was observed after 45 days. The detail description of efflorescence is given in Table 3. During the standard time period of seven days no efflorescence was observed but on extending the time of observation it occurred. Results illustrated that the efflorescence increased as the content of waste glass increased. As the waste glass was obtained from recycling and it contained more salts, that's why more efflorescence was observed on brick samples. However decrease in effloresce was observed with increase in burning temperature. The decrease in efflorescence at high temperature maybe mainly attributed due to verification that makes the structure denser and decrease porosity, consequently low porosity didnot allow the water to enter and cause efflorescence.

\section{CONCLUSIONS}

This study was conducted on the brick samples from the Punjab region and the impacts of percent increase of waste glass on bricks properties was observed. This research had five core objectives which were fulfilled as follows:

i. The main objective was to investigate the effect of waste glass addition on properties of burnt clay

\begin{tabular}{|c|c|c|c|}
\hline Sample & $\begin{array}{c}\text { Efflore } \\
\text { sce } \\
\text { Area } \\
(\%)\end{array}$ & Remarks & $\begin{array}{c}\% \\
\text { Diff }\end{array}$ \\
\hline $\begin{array}{c}0 \% \text { Waste } \\
\text { Glass }\end{array}$ & 10 & $\begin{array}{c}\text { Slight } \\
\text { Effloresce }\end{array}$ & 0 \\
\hline $\begin{array}{c}5 \% \text { Waste } \\
\text { Glass }\end{array}$ & 12 & $\begin{array}{l}\text { Moderate } \\
\text { Effloresce }\end{array}$ & $\begin{array}{c}16.6 \\
67\end{array}$ \\
\hline $\begin{array}{c}10 \% \text { Waste } \\
\text { Glass }\end{array}$ & 10 & $\begin{array}{c}\text { Slight } \\
\text { Effloresce }\end{array}$ & 0 \\
\hline $\begin{array}{c}15 \% \text { Waste } \\
\text { Glass }\end{array}$ & 15 & $\begin{array}{l}\text { Moderate } \\
\text { Effloresce }\end{array}$ & $\begin{array}{c}33.3 \\
33\end{array}$ \\
\hline $\begin{array}{c}20 \% \text { Waste } \\
\text { Glass }\end{array}$ & 20 & $\begin{array}{l}\text { Moderate } \\
\text { Effloresce }\end{array}$ & 50 \\
\hline
\end{tabular}

bricks. For the very purpose the main properties which were investigated were areal density, water absorption and efflorescence.

ii. To find the behavior of bricks in terms of its properties, such as, areal density, water absorption and efflorescence. ASTM C67-03a [15] tests standards were used to find areal density, water absorption and efflorescence of bricks.

iii. To accommodate powder glass in brick industry and use it as raw material for production of brick units. For this purpose waste glass was added as one of raw materials at different percentages by weight of bricks and total 150 brick specimens were prepared. Samples then burnt in kiln and oven after which their properties were studied.

iv. To craft an efficient method for reuse of waste glass with clay in bricks. For this purpose three properties of bricks namely efflorescence, water absorption and areal density were investigated in detail. As inferred from Figure 8, the increased percentage of powder glass in bricks resulted in reduction in weight of bricks. Also, the percent water absorption reduced with the addition of waste glass, which may be attributed with the non-absorption quality of the glass material (Figure 10). For Efflorescence, the controlled quantity of waste glass and at certain higher temperatures the results were remarkable on the scale of number of intermediate efflorescence during the considered observation time period 
(Table 3).

v. To make identification of powder glass as valuable product that could be used for production of brick units. From the above discussed results of properties it can be sum up that both oven and kiln burnt bricks shown the almost same trends for water absorption, efflorescence and areal density. The minor difference in their percentages depicted in graphs, Figure 8 and Figure 10, is only due to the fact that oven burnt bricks gained heat evenly from all sides. On the other side kiln did not provide even temperature to all sides of bricks. Further addition of waste glass as a raw material will save the other raw materials used in the production of bricks. It will have positive effect for sustainable use of raw materials. Secondly, waste glass can reduce the water absorption by bricks. Lastly, efflorescence was less in specimens having less quantity of waste glass burnt at higher temperatures. But as we increased the percentage of powder glass in brick efflorescence increased up to $50 \%$ (Table 3) and it shows we cannot use excess amount of powder glass in brick.

All in all the use of waste glass to certain amount usually less than $15 \%$ should be recommended as more percent addition may cause bulging of bricks.

\section{FUTURE RESEARCH}

In the future studies, the soil samples from all of the four provinces of Pakistan will be collected to comprehensively investigate the mechanical properties of bricks made of waste glass. Also, impacts of waste glass on compressive strength, flexural and splitting tensile strengths of bricks would be investigated. Addition of waste glass on bulging properties of bricks would be studied as a part of future studies. Tests on masonry assemblages (bricks containing waste glass) such as seismic evaluation and shear force determination etc. are also recommended. For the continuation of this study, the cost-benefit analysis of waste glass addition in bricks would also be evaluated. Besides this the effect of addition of waste glass in reinforced concrete should also be studied.

\section{ACKNOWLEDGEMENT}

The authors extend their appreciation to University of Engineering and Technology, Lahore for providing testing facilities to conduct this research study.

\section{REFERENCES}

1. Isa H., "The need for waste management in the glass industries: A review", Review Literature and Arts of the Americas, Vol. 3, No. July, pp. 276-279, 2008.

2. Kizinievič O., Žurauskiene R., Kizinievič V., Žurauskas R., Tumonis L., "Application of technogenic-raw material and burning out additive in composite ceramic system”, Medziagotyra, Vol. 18, No. 3, pp. 296302, 2012.

3. "Health and Safety - Clay Times Magazine", [Online]. Available: http://www.claytimes.com/referenceguide/health-safety.html. [Accessed: 01-Jan2019].

4. "Types of solid waste." [Online]. Available: http://edugreen.teri.res.in/explore/solwaste/types. htm. [Accessed: 01-Jan-2019].

5. EPA United States Environmental Protection Agency, "Containers and Packaging: ProductSpecific Data", Online Available at https://www.epa.gov/facts-and-figures-aboutmaterials-waste-and-recycling/containers-andpackaging-product-specific-data [Accessed: 02 January 2019].

6. Jani Y., Hogland W., "Waste glass in the production of cement and concrete - A review", Journal of Environmental Chemical Engineering, Vol. 2, No. 3, pp. 1767-1775, 2014.

7. Park S.B., Lee B. C., Kim J. H., "Studies on mechanical properties of concrete containing waste glass aggregate", Cement and Concrete Research, Vol. 34, No. 12, pp. 2181-2189, 2004.

8. Turgut P., "Properties of masonry blocks produced with waste limestone sawdust and glass powder", Construction and Building Materials, Vol. 22, No. 7, pp. 1422-1427, 2008.

9. Topçu I. B., Canbaz M., "Properties of concrete containing waste glass", Cement and Concrete Research, Vol. 34, No. 2, pp. 267-274, 2004. 
10. Demir I., "Reuse of waste glass in building brick production", Waste Management and Research, Vol. 27, No. 6, pp. 572-577, 2009.

11. Alvarez-Méndez A., Torres-González L. C., Alvarez N., Torres-Martínez L. M., "Kinetic thermal analysis of glass ceramics from industrial wastes", Journal of Non-Crystalline Solids, Vol. 329, No. 1-3, pp. 73-76, 2003.

12. Bragança S. R., Vicenzi J., Guerino K., Bergmann C. P., "Recycling of iron foundry sand and glass waste as raw material for production of whiteware", Waste Management and Research, Vol. 24, No. 1, pp. 60-66, 2006.

13. Manukyan R.V., Davydova N.S., "Use of Waste in the Ceramics Industry", Glass and Ceramics, Vol. 53, pp. 247-248, 1996.

14. Alsuwwi A.H., Hassan M., Awwad J. Ahmad N., "Comparative analysis of cement-sand \& cementsand-khaka (stone dust) mortar shear wall brick masonry materials", Masonry International, Vol. 28, No. 1, pp. 1-10, 2015.
15. ASTM C67-03a, Standard Test Methods for Sampling and Testing Brick and Structural Clay Tile, ASTM International, West Conshohocken, PA, 2003, www.astm.org.

16. Zhang L., "Production of bricks from Waste Materials - A Review", Construction and Building Materials, Vol.47. pp. 643-655, 2013.

17. Hameed A., Haider U., Qazi A., Abbas S., "Effect of waste glass on properties of burnt clay bricks", Pakistan Journal of Engineering and Applied Sciences, Vol. 22, pp. 56-63, 2018. 